\title{
ARTICLE
}

\section{Determination of Macro, Micro and Toxic Elements using Argon-Based Plasma Spectroanalytical Methods in order to support Brazilian Regulations on Inorganic Constituents in Infant Foods}

\author{
Marcelo Larsen de Lima Tozo, Fernanda Costa Pinheiro iD, Joaquim Araújo Nóbrega* iD \\ Group for Applied Instrumental Analysis, Department of Chemistry, Federal University of São Carlos \\ P.O. Box 676, São Carlos, SP, 13560-270, Brazil
}

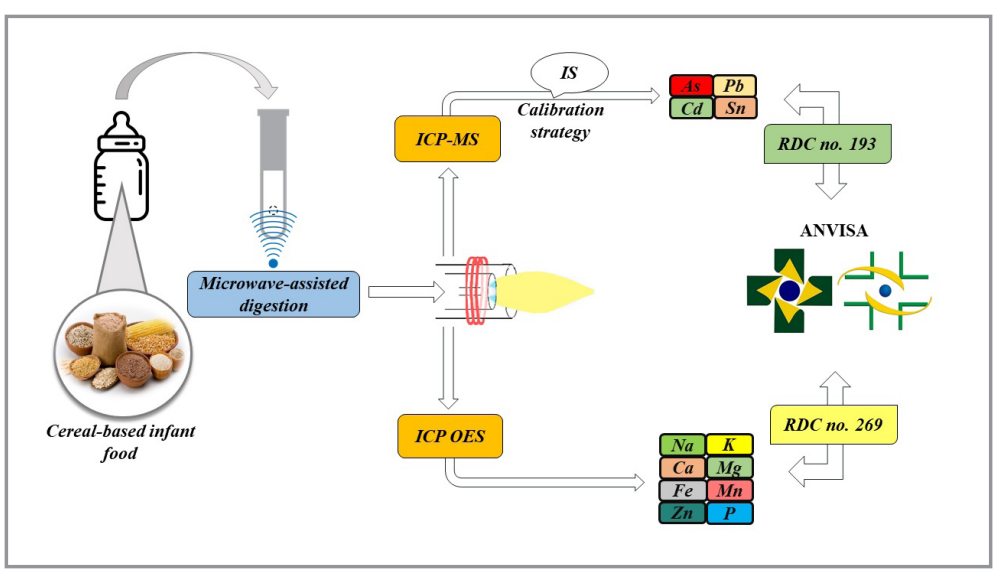

using inductively coupled plasma mass spectrometry (ICP-MS) for determination of As, Cd, Sn and Pb and inductively coupled plasma optical emission spectrometry (ICP OES) for determination of $\mathrm{Ca}, \mathrm{Fe}, \mathrm{K}, \mathrm{Mg}$, $\mathrm{Mn}, \mathrm{Na}, \mathrm{P}$ and $\mathrm{Zn}$ attending both Brazilian regulations. Microwave-assisted acid digestion of solid samples was carried out in closed vessels using $7 \mathrm{~mol} \mathrm{~L}^{-1} \mathrm{HNO}_{3}$. Two rice flours reference materials as well as addition and recovery experiments were applied to check accuracy. Recoveries ranged from 70 to $128 \%$ for ICP OES and from 82 to $128 \%$ for ICP-MS using internal standardization. The analytical procedure presented LOQs lower than maximum limits allowed by both regulations. Fifteen samples of cereal-based infant foods were analyzed and all analyte concentrations were lower than the respective MTLs recommended by RDC no. 193, except to $\mathrm{Pb}$ concentration in one milk flour sample. According to the RDI established by RDC no. 269 and the average concentrations of $\mathrm{Ca}, \mathrm{Fe}, \mathrm{K}, \mathrm{Mg}, \mathrm{Mn}, \mathrm{P}$ and $\mathrm{Zn}$ in samples, it was possible to assign a minimum mass value of food that meets the recommendations of the Brazilian resolution for different population groups.

Keywords: Sample preparation, ANVISA Resolution 193, ANVISA Resolution 269, ICP-MS, ICP OES.

Cite: Tozo, M. L. L.; Pinheiro, F. C.; Nóbrega, J. A. Determination of Macro, Micro and Toxic Elements using Argon-Based Plasma Spectroanalytical Methods in order to support Brazilian Regulations on Inorganic Constituents in Infant Foods. Braz. J. Anal. Chem., 2021, 8 (31), pp 74-88. doi: http://dx.doi.org/10.30744/brjac.2179-3425.AR-50-2020

Received 15 September 2020, Revised 21 December 2020, $2^{\text {nd }}$ time Revised 17 January 2021, Accepted 19 January 2021, Available online 23 February 2021. 


\section{INTRODUCTION}

Good nutrition is vital for human health. In this sense, it is known that cereal grains are important in human health and also a good source of energy and dietary fibers as well as proteins and essential elements, especially for children and newborns during development phase [1]. Despite the nutritional important roles of cereal grains in the human diet, cereal-based foods, commonly present in the diet of children and newborns, are a possible source of exposure to contaminants, such as $\mathrm{As}, \mathrm{Cd}, \mathrm{Pb}$ and $\mathrm{Sn}$, also known as potentially toxic elements (PTEs) [2-7].

Contamination by some PTEs, even in low concentrations, can be harmful to health, causing diseases and irreversible damage to the body. Because children differ regarding their physiology and metabolism, the contamination risk can be more severe $[8,9]$. Exposure to environmental threats at these sensitive stages of the child's life may negatively influence the growth and development and also cause irreversible damage, such as injury to the liver, kidneys, bones, lungs, central nervous system, cardiovascular diseases and even cancerous effects [10].

Associated with the control of PTEs in foods, the interest in the determination of $\mathrm{As}, \mathrm{Cd}, \mathrm{Sn}$ and $\mathrm{Pb}$ in infant foods is also related to the fulfillment of Brazilian legislations, including the Resolution RDC no. 193, of December 2017, which establishes Maximum Tolerated Limits (MTLs) of these contaminants in infant foods and cereal-based lactating foods [11]. In addition to RDC no. 193, the Resolution no. 269, of September 2005, recommends the determination of macro and microelements based on values of recommended daily intake (RDI) of proteins, vitamins and minerals for individuals in different population groups [12].

According to Damodaran et al. [13] the variation in the deficiency of some elements, rare or practically nonexistent in the human body, is due to socio-economic issues and geographical divisions. However, plant-based foods are the main sources of macro and microelements to satisfy nutritional needs. In biological systems, elemental nutrients are separated into two categories: macroelements (elements in higher concentrations in human body, such as $\mathrm{Ca}, \mathrm{K}, \mathrm{Mg}, \mathrm{Na}$ and $\mathrm{P}$ ) and microelements (elements present in lower concentrations in human body, but which perform important functions for normal metabolism of human beings, such as $\mathrm{Co}, \mathrm{Cr}, \mathrm{Cu}, \mathrm{Fe}, \mathrm{Mn}$ and $\mathrm{Zn})[3,13]$.

Spectrochemical methods with atomization-excitation-ionization in argon plasmas are widely used for elemental determination providing multi-element analysis, high sensitivity, robustness and relatively simple operation of equipment [14-16]. Due to the high sensitivity and low detection limits argon-based plasma methods are intensely used for determination of inorganic contaminants at trace concentrations in several types of food samples [15-17]. Additionally, the combination of microwave-assisted digestion and closed vessels has clear advantages compared to traditional acid digestion using conventional heating and open vessels in terms of better recoveries for volatile elements, lower contamination, lower volume of reagents, better reproducibility and a better working environment [18].

In this context, this study proposed a microwave-assisted digestion procedure using dilute nitric acid solutions for determination of $\mathrm{As}, \mathrm{Cd}, \mathrm{Sn}$ and $\mathrm{Pb}$ using ICP-MS and $\mathrm{Ca}, \mathrm{Fe}, \mathrm{K}, \mathrm{Mg}, \mathrm{Mn}, \mathrm{Na}, \mathrm{P}$ and $\mathrm{Zn}$ using ICP OES in several types of children's foods and supplements in order to meet simultaneously both Brazilian resolutions: RDC no. 193 and RDC no. 269. Instrumental strategies for correcting spectral interferences as well as calibration methods for non-spectral interferences were evaluated in order to improve accuracy and precision of the analytical procedure using either ICP-MS or ICP OES. Fifteen samples of cereal-based infant foods were analyzed and all analyte concentrations were lower than the respective MTLs recommended by RDC no. 193, except to $\mathrm{Pb}$ concentration in one milk flour sample. According to the RDI from RDC no. 269 and the average concentrations of $\mathrm{Ca}, \mathrm{Fe}, \mathrm{K}, \mathrm{Mg}, \mathrm{Mn}, \mathrm{P}$ and $\mathrm{Zn}$ in samples, it was possible to assign a minimum mass value of food that meets the recommendations of the Brazilian resolution for four different population children groups. 


\section{MATERIALS AND METHODS}

\section{Samples and sample preparation}

Fifteen samples of children's foods and supplements (coded from A1 to A15) were analyzed. Samples A1, A2 and A3 were purchased in commercial establishments (as normally sold in commercial packaging) in São Carlos, SP, Brazil, and all other samples were supplied by the Laboratory Exata located in Jataí, GO, Brazil also as they are normally sold. Samples, types and their nutritional indication are presented in Table I. These samples were produced by several food companies (Danone, Maisena, Nestle, Sustagen and Yoki) in four Brazilian states. One sample came from Buenos Aires, Argentina.

Table I. Samples of children's foods and supplements and their food indication according to the commercial label of each food

\begin{tabular}{lll}
\hline Sample & Type of infant food & Indication \\
\hline A1 & Infant Cereal - Rice & Children over 6 months \\
A2 & Corn Starch with Rice Flour & Children over 2 years \\
A3 & Rice Cream & Children over 2 years \\
A4 & Milk Flour & Children over 2 years \\
A5 & Infant Formula & Infants from 0 to 6 months \\
A6 & Milk Flour & Children over 2 years \\
A7 & Infant Cereal - Rice and Oats & Children over 6 months \\
A8 & Infant Cereal - Corn & Children over 6 months \\
A9 & Infant Formula & Infants over 5 months \\
A10 & Infant Cereal - Multicereals & Children over 6 months \\
A11 & Sustagen & Children over 6 months \\
A12 & Infant Formula & Infants over 9 months \\
A13 & Powdered Milk & Children over 1 year \\
A14 & Powdered Millk & Children over 1 year \\
A15 & Infant Formula & Infants from 0 to 6 months \\
\hline
\end{tabular}

Masses of approximately $500 \mathrm{mg}$ of each sample were weighed in perfluoroalkoxy-alkane (PFA) digestion vessels and digested in a single reaction chamber (SRC) system (UltraWave ${ }^{\mathrm{TM}}$, Milestone, Sorisole, BG, Italy). Volumes of $150 \mathrm{~mL}$ of water and $5 \mathrm{~mL}$ of concentrated nitric acid were inserted into the SRC and the chamber was pressurized with nitrogen gas to 40 bar (99.9\%, White Martins-Praxair, Sertãozinho, SP, Brazil) as recommended by the manufacturer. Volumes of $5 \mathrm{~mL}$ of $\mathrm{HNO}_{3}$ in three different concentrations $\left(1 ; 2\right.$ and $\left.7 \mathrm{~mol} \mathrm{~L}^{-1}\right)$ were tested for digestion of food samples. The microwave heating program was applied as follows [18]: (1) $2.5 \mathrm{~min}$ to reach $140{ }^{\circ} \mathrm{C}$, (2) $2.5 \mathrm{~min}$ hold at $140{ }^{\circ} \mathrm{C}$, (3) $2.5 \mathrm{~min}$ to reach $180^{\circ} \mathrm{C}$, (4) 2.5 min hold at $180^{\circ} \mathrm{C}$, (5) $10 \mathrm{~min}$ to reach $220^{\circ} \mathrm{C}$, (6) $10 \mathrm{~min}$ hold at $220^{\circ} \mathrm{C}$. Temperature was controlled by an internal temperature sensor.

Subsequently, digests were diluted to $25.0 \mathrm{~mL}$ with distilled-deionized water and an aliquot of each solution was appropriately diluted with deionized water, followed by quantification by ICP OES (10-fold dilution) using external calibration and by ICP-MS (2-fold dilution) using internal standardization. 


\section{Reagents and standard solutions}

Experiments were performed using $\mathrm{HNO}_{3}$ (Synth, Diadema, SP, Brazil) purified in a sub-boiling distillation apparatus Distillacid ${ }^{\mathrm{TM}}$ BSB-939-IR (Berghof, Eningen, Germany) and ultrapure water with resistivity higher than $18.2 \mathrm{M} \Omega \mathrm{cm}$ (Milli-Q ${ }^{\circledR}$ Bedford, MA, USA). All glass and polypropylene bottles were washed and kept in an acid bath $\left(\mathrm{HNO}_{3} 10 \% \mathrm{v} / \mathrm{v}\right)$ for $24 \mathrm{~h}$. The standard solutions used for calibration and for addition and recovery experiments were prepared by adequate dilution of mono-elementar stock solutions containing $1000 \mathrm{mg} \mathrm{L}^{-1}$ of As, Ca, Cd, Fe, K, Mg, Mn, Na, P, Pb, Sn and Zn (Qhemis, Jundiaí, SP, Brazil) in $0.7 \mathrm{~mol} \mathrm{~L}^{-1}$ $\mathrm{HNO}_{3}$ medium. The internal standards evaluated (ISs) were also prepared by adequate dilution of monoelementar stock solutions containing $1000 \mathrm{mg} \mathrm{L}^{-1}$ of $\mathrm{Ge}, \mathrm{Pd}$ and $\mathrm{Y}$. These elements were evaluated as IS based on previous studies [18-20].

The concentrations for analytical calibration solutions used in ICP-MS were 0, 0.05, 0.1, 0.5, 1.0, 5.0, 10.0 and $20.0 \mu \mathrm{g} \mathrm{L}^{-1}$ of $\mathrm{As}, \mathrm{Cd}, \mathrm{Sn}$ and $\mathrm{Pb}$ prepared in $0.14 \mathrm{~mol} \mathrm{~L}^{-1} \mathrm{HNO}_{3}$ medium. Addition and recovery experiments were performed at two levels of addition: 0.50 and $1.0 \mu \mathrm{g} \mathrm{L}^{-1}$ for all analytes in four different samples: A1 (Infant cereal of rice); A3 (Rice cream); A9 (Infant formula) and A13 (Powdered Milk). The standards were added before sample digestions. To correct for matrix effects, the evaluated ISs $\mathrm{Ge}, \mathrm{Pd}$ and $Y$ were added at $1.0 \mu \mathrm{L} \mathrm{L}^{-1}$ to analytical calibration solutions, analytical blanks, and sample digests. For addition and recovery experiments the ISs were added at same concentration for both addition levels.

For ICP OES, the concentrations for analytical calibration solutions were $0,0.01,0.05,0.1,0.5,1.0$, 5.0, 10, 25 and $50 \mathrm{mg} \mathrm{L}^{-1}$ of $\mathrm{Ca}, \mathrm{Fe}, \mathrm{K}, \mathrm{Mg}, \mathrm{Mn}, \mathrm{Na}, \mathrm{P}$ and $\mathrm{Zn}$ prepared in $0.70 \mathrm{~mol} \mathrm{~L}^{-1} \mathrm{HNO}_{3}$ medium. Matrix effects were not observed using ICP OES and, consequently, ISs were not added. Addition and recovery experiments were not performed for ICP OES analysis because both reference materials have certified values for all analytes. The certified reference material (CRM) of rice flour NIST 1568a (National Institute of Standard and Technology, Gaithersburg, MD, EUA) and the reference material (RM) also of rice flour Agro AR-01/2015 (Embrapa Pecuária Sudeste, São Carlos, SP, Brazil) were used for optimization of experimental procedures and evaluation of accuracy for ICP OES and ICP-MS. For ICP-MS, addition and recovery experiments were also considered because both reference materials did not inform reference concentrations for Pb and Sn. CRM NIST 1568a has certified values for As and Cd. On the other hand, RM Agro AR-01/2015 only has certified value for As.

\section{Instrumentation}

Measurements were performed using an ICP OES model iCAP6000 (Thermo Fisher Scientific, Waltham, MA, USA) operated under robust conditions and axial viewing mode and an ICP-MS model Agilent 7800 Quadrupole (Agilent Technologies, Tokyo, JHS, Japan) without using collision cell (standard mode) or using collision cell technology (He mode) pressurized with He gas (99.999\%, White MartinsPraxair, Sertãozinho, SP, Brazil) both applying the aerosol dilution strategy, i.e. the aerosol was diluted with argon under adjusted flow rates (aerosol dilution gas flow rate of $0.62 \mathrm{~L} \mathrm{~min}^{-1}$ and carrier gas flow rate of $0.40 \mathrm{~L} \mathrm{~min}^{-1}$, thus $1.02 \mathrm{~L} \mathrm{~min}^{-1}$ of total flow rate [20]. Argon (99.999\%, White Martins-Praxair) was used in all measurements for both instruments. Plasma operating conditions adopted in ICP-MS and ICP OES are presented in Table II.

Table II. Instrumental parameters adopted in ICP OES and Quadrupole ICP-MS

\begin{tabular}{lcc}
\hline Instrumental Parameter & ICP OES & ICP-MS \\
\hline RF applied power $(\mathrm{kW})$ & 1.20 & 1.55 \\
Plasma gas flow rate $(\mathrm{L} \mathrm{min}-1)$ & 12 & 15 \\
Auxiliary gas flow rate $\left(\mathrm{L} \mathrm{min}^{-1}\right)$ & 0.5 & 1.0 \\
Carrier gas flow rate $(\mathrm{L} \mathrm{min}-1)$ & 0.50 & 1.02 \\
Carrier gas flow rate in $\mathrm{HMI}$ mode $\left(\mathrm{L} \mathrm{min}^{-1}\right)$ & $\mathrm{NA}$ & 0.40 \\
\hline
\end{tabular}


Table II. Instrumental parameters adopted in ICP OES and Quadrupole ICP-MS (Continuation)

\begin{tabular}{|c|c|c|}
\hline Instrumental Parameter & ICP OES & ICP-MS \\
\hline HMI gas flow rate $\left(\mathrm{L} \mathrm{min}^{-1}\right)$ & NA & 0.62 \\
\hline Sampling depth (mm) & NA & 8.0 \\
\hline He flow rate in collision cell $\left(\mathrm{mL} \mathrm{min}^{-1}\right)$ & NA & 4.5 \\
\hline Integration time (s) & 15 & 3.0 \\
\hline Nebulizer & V-Groove & Mira-Mist \\
\hline Spray chamber & Cyclonic & Double-pass \\
\hline Number of replicates & 3 & 3 \\
\hline Analyte & Emission Line (nm) & Isotope $(\mathrm{m} / \mathrm{z})$ \\
\hline As & NA & 75 \\
\hline $\mathrm{Ca}$ & 184.006 & NA \\
\hline $\mathrm{Cd}$ & NA & 114 \\
\hline $\mathrm{Fe}$ & 238.204 & NA \\
\hline K & 769.896 & NA \\
\hline $\mathrm{Mg}$ & 279.079 & NA \\
\hline $\mathrm{Mn}$ & 259.373 & NA \\
\hline $\mathrm{Na}$ & 330.237 & NA \\
\hline$P$ & 178.284 & NA \\
\hline $\mathrm{Pb}$ & NA & 208 \\
\hline Sn & NA & 120 \\
\hline $\mathrm{Ge}$ & NA & 70 \\
\hline $\mathrm{Pd}$ & NA & 104 \\
\hline Y & NA & 89 \\
\hline $\mathrm{Zn}$ & 202.548 & NA \\
\hline
\end{tabular}

NA: Not applicable.

\section{RESULTS AND DISCUSSION}

\section{Microwave-assisted sample preparation}

The preliminary assessment of the digestion procedure was carried out visually since the goal was to reach digestion without residual solids for all analyzed samples. Residual solids were observed for samples digested using 1 and $2 \mathrm{~mol} \mathrm{~L}^{-1} \mathrm{HNO}_{3}$. Thus, a solution containing $7 \mathrm{~mol} \mathrm{~L}^{-1} \mathrm{HNO}_{3}$ was selected for further experiments since complete and clear digests were obtained for all samples without adding hydrogen peroxide. The sample preparation procedure using only $1+1 \mathrm{v} / \mathrm{v}$ dilute nitric acid solution is attractive because the use of hydrogen peroxide may sometimes imply in the addition of contaminants when not using a high purity reagent $[16,18,21]$. 


\section{Analytical performance for ICP OES and ICP-MS}

Limits of detection (LOD) and quantification (LOQ) were calculated considering standard deviation (SD) for 10 measurements of a blank solution divided by slope of analytical curve multiplied by 3 (LOD) and 10 (LOQ), and then multiplied by the dilution factor [22]. For ICP-MS, measured isotopes, mode of acquisition, linear correlation coefficient and LOQs are shown in Table III. The LOQs obtained for all analytes were lower than the respective MTL suggested by RDC no. 193 [11], inferring that the developed procedure has sufficient detectability to meet this resolution.

Table III. Maximum tolerable limits (MTL) and figures of merit for determination of $\mathrm{As}, \mathrm{Cd}, \mathrm{Pb}$ and Sn by ICP-MS using external calibration and internal standardization

\begin{tabular}{ccccc}
\hline Isotope & ${ }^{75} \mathbf{A s}^{+}$ & ${ }^{114} \mathbf{C d}^{+}$ & ${ }^{120} \mathbf{S n}^{+}$ & ${ }^{208} \mathbf{P b}^{+}$ \\
\hline Acquisition mode & $\mathrm{He}$ & Standard & Standard & Standard \\
$\mathrm{MTL}^{\mathrm{a}}\left(\mathrm{mg} \mathrm{kg}^{-1}\right)$ & 0.15 & 0.050 & 50 & 0.050 \\
\hline \multicolumn{4}{c}{ External Calibration } \\
\hline Sensitivity & 956 & 2076 & 4464 & 4842 \\
$\mathrm{R}^{2}$ & 0.9999 & 0.9998 & 0.9999 & 0.9997 \\
LOD $\left(\mathrm{mg} \mathrm{kg}^{-1}\right)$ & 0.0031 & 0.00050 & 0.0069 & 0.0087 \\
LOQ $\left(\mathrm{mg} \mathrm{kg}^{-1}\right)$ & 0.010 & 0.0020 & 0.023 & 0.029 \\
\hline & & $\mathrm{Y}$ & $\mathrm{Y}$ & \\
\hline Internal Standard & 0.9993 & 0.9992 & 0.9994 & $\mathrm{Y}$ \\
$\mathrm{R}^{2}$ & 0.0038 & 0.00050 & 0.0076 & 0.9990 \\
LOD $\left(\mathrm{mg} \mathrm{kg}^{-1}\right)$ & 0.013 & 0.0020 & 0.025 & 0.0093 \\
LOQ $\left(\mathrm{mg} \mathrm{kg}^{-1}\right)$ & & $\mathrm{Y}$ & 0.031 \\
\hline
\end{tabular}

${ }^{a}$ Resolution no. 193, of December 12, 2017 [11].

For ICP-MS measurements, sample dilution is often necessary to keep the total dissolved solids (TDS) below $0.1 \% \mathrm{~m} / \mathrm{v}$. To overcome this limitation and improve the sensitivity, ICP-MS was operated using aerosol dilution strategy. This instrumental strategy enabled the introduction of digests with TDS of up to $0.5 \% \mathrm{~m} / \mathrm{v}$ and residual acidity up to $1 \% \mathrm{v} / \mathrm{v}$, which eliminates possible contamination associated with manual dilution, saves time and reduces the volume of waste compared to conventional dilution using a liquid diluent $[18,20]$.

ICP-MS is susceptible to spectral and non-spectral interferences due to matrix effects associated with transport, nebulization, and/or energetic effects in argon plasma [15,16]. Consequently, internal standardization was used as calibration strategy to correct matrix effects in the determination of all analytes. Furthermore, the instrumental strategy of collision cell technology (CCT) with kinetic energy discrimination (KED) was adopted to correct spectral interferences when determining As. The CCT is an instrumental strategy used for removing spectral interferences caused by polyatomic species [23]. The collision cell mode was used only for determination of As, due to possible interferences caused in the mass/charge 75 , such as ${ }^{40} \mathrm{Ca}^{35} \mathrm{Cl}^{+}$and ${ }^{59} \mathrm{Co}^{16} \mathrm{O}^{+}$. For all other elements, adequate accuracy was obtained using the standard mode acquisition.

Measurements using ICP OES were performed in axial configuration for improving sensitivity. Table IV presents the reached limits of quantification (LOQ) for determination of $\mathrm{Ca}, \mathrm{Fe}, \mathrm{K}, \mathrm{Mg}, \mathrm{Mn}, \mathrm{Na}, \mathrm{P}$ and $\mathrm{Zn}$ using ICP OES. 
Table IV. Analytical parameters for determination of $\mathrm{Ca}, \mathrm{Fe}, \mathrm{K}, \mathrm{Mg}, \mathrm{Mn}, \mathrm{Na}, \mathrm{P}$ and $\mathrm{Zn}$ by ICP OES using external calibration

\begin{tabular}{ccccc}
\hline Element & Sensitivity & $\mathbf{R 2}$ & $\begin{array}{c}\text { LOD } \\
(\mathbf{m g ~ k g}\end{array}$ & $\begin{array}{c}\text { LOQ } \\
\left(\mathbf{m g ~ k g}^{-1}\right)\end{array}$ \\
\hline $\mathrm{Ca}$ & 1019 & 0.9999 & 3.5 & 12 \\
$\mathrm{Fe}$ & 95 & 0.9999 & 0.060 & 0.19 \\
$\mathrm{~K}$ & 13077 & 0.9998 & 0.48 & 1.6 \\
$\mathrm{Mg}$ & 7306 & 0.9998 & 0.51 & 1.7 \\
$\mathrm{Mn}$ & 54727 & 0.9998 & 0.013 & 0.042 \\
$\mathrm{Na}$ & 1497 & 0.9999 & 8.7 & 29 \\
$\mathrm{P}$ & 129 & 0.9998 & 1.9 & 6.3 \\
$\mathrm{Zn}$ & 24067 & 0.9996 & 0.55 & 1.8 \\
\hline
\end{tabular}

\section{Evaluation of accuracy for ICP OES and ICP-MS procedures}

For ICP-MS measurements, the accuracy of the developed analytical procedure was evaluated by addition and recovery experiments at two-levels $\left(0.50\right.$ and $\left.1.0 \mu \mathrm{g} \mathrm{L}^{-1}\right)$ applied to four samples with different compositions (infant cereal, rice cream, infant formula and powdered milk) and also by analysis of CRM NIST 1568a and RM Agro AR-01/2015, both composed by flour rice. The addition levels of spike experiments were performed based on the specific MTL for each analyte by means of RDC no. 193 [11] (Table III). Spikes were added before microwave-assisted digestion. Table $V$ presents the recoveries obtained for addition and recovery experiments using external calibration and internal standardization. Considering the CRM and RM analyzed, only As (0.29 \pm 0.03 and $0.112 \pm 0.015 \mathrm{mg} \mathrm{kg}^{-1}$, respectively) and Cd $(0.022 \pm$ $0.002 \mathrm{mg} \mathrm{kg}^{-1}$ for the CRM) presented certified values. For As, recoveries of $101 \%\left(0.30 \pm 0.03 \mathrm{mg} \mathrm{kg}^{-1} \mathrm{of}\right.$ As for CRM) and $106 \%$ (0.12 $\pm 0.01 \mathrm{mg} \mathrm{kg}^{-1}$ of As for RM) were obtained for both materials. For Cd, only

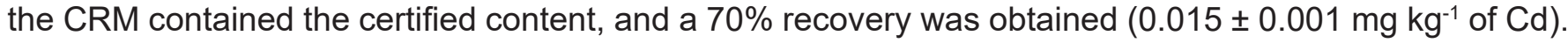

Table V. Addition and recovery experiments (recovery (\%), RSD (\%), $n=3$ ) by ICP-MS using external calibration and internal standardization

\begin{tabular}{|c|c|c|c|c|c|}
\hline \multirow{2}{*}{ Isotope } & \multirow{2}{*}{ Adition ( $\left.\mu \mathrm{g} \mathrm{L}^{-1}\right)$} & \multicolumn{4}{|c|}{ External Calibration } \\
\hline & & A1 & A3 & A9 & A13 \\
\hline \multirow{2}{*}{${ }^{75} \mathrm{As}^{+}$} & 0.5 & $51(4)$ & $79(8)$ & $84(6)$ & $86(3)$ \\
\hline & 1 & $63(7)$ & $79(2)$ & $83(2)$ & $79(4)$ \\
\hline \multirow{2}{*}{${ }^{114} \mathrm{Cd}^{+}$} & 0.5 & $85(7)$ & $95(9)$ & $72(2)$ & $74(6)$ \\
\hline & 1 & $83(4)$ & $91(2)$ & $73(4)$ & $75(6)$ \\
\hline \multirow{2}{*}{${ }^{120} \mathrm{Sn}^{+}$} & 0.5 & $88(5)$ & $90(4)$ & $105(6)$ & $82(3)$ \\
\hline & 1 & $87(7)$ & $88(1)$ & $95(9)$ & $80(7)$ \\
\hline \multirow{2}{*}{${ }^{208} \mathrm{~Pb}^{+}$} & 0.5 & $94(8)$ & $101(9)$ & $113(6)$ & $94(7)$ \\
\hline & 1 & $89(4)$ & $103(10)$ & $94(6)$ & $93(25)$ \\
\hline
\end{tabular}


Table V. Addition and recovery experiments (recovery (\%), RSD (\%), $n=3$ ) by ICP-MS using external calibration and internal standardization (Continuation)

\begin{tabular}{lccccc}
\hline \multirow{2}{*}{ Isotope } & Adition $\left(\boldsymbol{\mu g ~ \mathrm { L } ^ { - 1 }}\right)$ & \multicolumn{4}{c}{ Internal Standardization } \\
\cline { 2 - 5 } & 0.5 & $\mathbf{A} 1$ & $\mathbf{A 3}$ & $\mathbf{A 9}$ & $\mathbf{A 1 3}$ \\
\hline${ }^{75} \mathrm{As}^{+}$ & 1 & $85(6)$ & $84(4)$ & $86(4)$ & $96(4)$ \\
& 0.5 & $93(7)$ & $86(1)$ & $82(3)$ & $90(3)$ \\
${ }^{114} \mathrm{Cd}^{+}$ & 1 & $90(4)$ & $108(5)$ & $82(2)$ & $85(7)$ \\
& 0.5 & $94(6)$ & $97(3)$ & $85(6)$ & $87(5)$ \\
${ }^{120} \mathrm{Sn}^{+}$ & 1 & $94(7)$ & $94(1)$ & $96(7)$ & $92(4)$ \\
& 0.5 & $102(7)$ & $104(8)$ & $87(8)$ & $91(5)$ \\
${ }^{208} \mathrm{~Pb}^{+}$ & 1 & $96(3)$ & $108(11)$ & $97(6)$ & $98(6)$ \\
& & & & $87(9)$ & $102(23)$ \\
\hline
\end{tabular}

The choice of IS was evaluated by addition and recovery experiments and also by analysis of CRM NIST 1568a and RM Agro AR-01/2015. Among the ISs evaluated (Ge, Pd and Y), the best recoveries, ranging from 82 to $108 \%$, were obtained for all analytes when using $Y$ as IS, but satisfactory recoveries were also obtained when using ${ }^{70} \mathrm{Ge}^{+}$as internal standard for ${ }^{75} \mathrm{As}^{+},{ }^{120} \mathrm{Sn}^{+}$and ${ }^{208} \mathrm{~Pb}^{+}$, as also observed in previous studies [18,20]. Since RDC no. 193 [11] does not specify a validation parameter, recoveries ranging from 80 to $120 \%$ were considered satisfactory.

The improvement in recoveries using internal standardization can be explained due to the correction of matrix effects caused during transport and/or ionization of analytes. In general, it is accepted that a good IS should have physico-chemical properties similar to the analytes, such as similar isotopic mass between the IS and the analyte [24] or the first ionization energy [25]. However, recent studies have demonstrated divergences in the literature related to IS selection criteria in ICP-MS [19,20,26,27]. According to Olesik and Jiao $[26,27]$ and Barros et al. $[19,20]$ in current ICP-MS instruments is not always necessary to have analyte and IS with similar masses probably due to the different behavior of space charge effects in current ion lenses design. This new assumption might explain why a single IS, sometimes with highly different mass and physico-chemical parameters, is effective for correcting matrix effects, as also observed here.

For ICP OES measurements, recoveries ranged from 70 to $128 \%$ for the RM of rice flour Agro AR$01 / 2015$ and from 85 to $123 \%$ for the CRM NIST 1568a inferring that the analytical procedure developed for determination of macro and micro elements in baby food samples using ICP OES is accurate. Some elements i.e., $\mathrm{Ca}, \mathrm{Na}$ and $\mathrm{K}$, presented recoveries slightly out of range considered quantitative (from 80 to $120 \%$ ), however, for just one of the evaluated RMs. No significant matrix effects were observed for ICP OES measurements, i.e. matrix effects observed in ICP OES were reduced in comparison to ICP-MS. Therefore, internal standardization was not required. Table VI shows certified and determined contents obtained for both reference materials.

Along with the contents shown in Table VI, F-test with 95\% of confidence and paired Student's $t$-test were applied to evaluate agreement between certified and determined values for each element in both reference materials. The t-test was performed assuming unequal variances for $\mathrm{Zn}$ on RM Agro and $\mathrm{Fe}, \mathrm{K}$, $\mathrm{Mg}$ and $\mathrm{Na}$ on NIST SRM and equal variances for the others elements according to the F-test previously made. Under the calculated conditions $(n=3)$, with $95 \%$ confidence $\left(t_{95 \%}=2.78\right), M g$ and $P$ had shown significant differences (3.19 and 3.08, respectively) for the RM Agro AR-01/2015, and also K and Zn had shown significant differences (36.4 and 5.44, respectively) for the CRM NIST 1568a. Adopting 99\% confidence level $\left(\mathrm{t}_{99 \%}=4.60\right)$, only $\mathrm{K}$ had shown significant difference for the CRM NIST 1568a. 
Table VI. Certified and determined contents (mean \pm standard deviation, $\mathrm{mg} \mathrm{kg}^{-1}, \mathrm{n}=3$ ), recoveries $(\%)$, Student's t-test obtained for RM Agro AR-01/2015 and CRM NIST 1568a using ICP OES

\begin{tabular}{lcccccc}
\hline \multirow{2}{*}{ Element } & \multicolumn{3}{c}{ RM Agro AR-01/2015 } & \multicolumn{3}{c}{ NIST SRM 1568a } \\
\cline { 2 - 7 } & Certified value & Determined value & $\boldsymbol{t}$ value & Certified value & Determined value & $\boldsymbol{t}$ value \\
\hline $\mathrm{Ca}$ & $90 \pm 32$ & $114 \pm 3(128)$ & 0.75 & $118 \pm 6$ & $106 \pm 1(91)$ & 1.97 \\
$\mathrm{Fe}$ & $17 \pm 1$ & $17.32 \pm 0.05(102)$ & 0.32 & $7.4 \pm 0.9$ & $6.2 \pm 0.3(87)$ & 1.26 \\
$\mathrm{~K}$ & $1852 \pm 319$ & $1908 \pm 20(103)$ & 0.18 & $1280 \pm 8$ & $1591 \pm 3(123)$ & 36.4 \\
$\mathrm{Mg}$ & $1258 \pm 116$ & $1620 \pm 20(120)$ & 3.08 & $560 \pm 20$ & $513 \pm 3(92)$ & 2.32 \\
$\mathrm{Mn}$ & $62 \pm 4$ & $67.0 \pm 0.6(109)$ & 1.24 & $20 \pm 2$ & $16.86 \pm 0.07(85)$ & 1.57 \\
$\mathrm{Na}$ & $117 \pm 28$ & $82 \pm 3(70)$ & 1.24 & $<\mathrm{LOD}$ & $<$ LOD & $\mathrm{NA}$ \\
$\mathrm{P}$ & $3037 \pm 184$ & $3631 \pm 28(119)$ & 3.19 & $1530 \pm 80$ & $1454 \pm 15(96)$ & 0.93 \\
$\mathrm{Zn}$ & $19 \pm 3$ & $23 \pm 1(119)$ & 1.26 & $19.4 \pm 0.5$ & $16.66 \pm 0.6(86)$ & 3.51 \\
\hline
\end{tabular}

NA: Not applicable.

\section{Sample analysis}

After optimizing the analytical parameters for determination of macro, micro and toxic elements using argon-based plasma spectrochemical methods, fifteen samples of infant foods and supplements were analyzed (Tables VII and VIII). For toxic elements (Table VII), the concentration ranges determined in the samples were 0.026 to $0.14 \mathrm{mg} \mathrm{kg}^{-1}$ for As and 0.029 to $0.097 \mathrm{mg} \mathrm{kg}^{-1}$ for Sn. For Cd, only two samples (A6 and $A 7$ contained 0.002 and $0.009 \mathrm{mg} \mathrm{kg}^{-1}$ of $\mathrm{Cd}$, respectively) contained concentrations higher than the respective $\mathrm{LOQ}$. For $\mathrm{Pb}$, only one sample (A6, $0.07 \mathrm{mg} \mathrm{kg}^{-1}$ ) was higher than the $\mathrm{LOQ}$ established for $\mathrm{Pb}$. However, all determined concentrations for these elements were lower than the limits proposed by RDC no. 193 [11], except to $\mathrm{Pb}$ for sample A6.

Table VII. Determination of $\mathrm{As}, \mathrm{Cd}, \mathrm{Sn}$ and $\mathrm{Pb}$ in samples of infant foods and supplements (mean \pm standard deviation, $\mathrm{mg} \mathrm{kg}^{-1}, \mathrm{n}=3$ ) using ICP-MS

\begin{tabular}{lcccc}
\hline Sample & ${ }^{75} \mathrm{As}^{+}$ & ${ }^{114} \mathbf{C d}^{+}$ & ${ }^{120} \mathbf{S n}^{+}$ & ${ }^{208} \mathrm{~Pb}^{+}$ \\
\hline A1 & $0.14 \pm 0.02$ & $<0.0020$ & $<0.025$ & $<0.031$ \\
A2 & $<0.013$ & $<0.0020$ & $<0.025$ & $<0.031$ \\
A3 & $0.1333 \pm 0.0005$ & $<0.0020$ & $<0.025$ & $<0.031$ \\
A4 & $<0.013$ & $<0.0020$ & $<0.025$ & $<0.031$ \\
A5 & $<0.013$ & $<0.0020$ & $0.03 \pm 0.01$ & $<0.031$ \\
A6 & $<0.013$ & $0.002 \pm 0.001$ & $<0.025$ & $0.07 \pm 0.03$ \\
A7 & $0.09 \pm 0.01$ & $0.009 \pm 0.001$ & $<0.025$ & $<0.031$ \\
A8 & $<0.013$ & $<0.0020$ & $<0.025$ & $<0.031$ \\
A9 & $<0.013$ & $<0.0020$ & $0.097 \pm 0.002$ & $<0.031$ \\
A10 & $<0.013$ & $<0.0020$ & $<0.025$ & $<0.031$ \\
A11 & $<0.013$ & $<0.0020$ & $<0.025$ & $<0.031$ \\
A12 & $<0.013$ & $<0.0020$ & $0.060 \pm 0.005$ & $<0.031$ \\
\hline
\end{tabular}


Table VII. Determination of $\mathrm{As}, \mathrm{Cd}, \mathrm{Sn}$ and $\mathrm{Pb}$ in samples of infant foods and supplements (mean \pm standard deviation, $\mathrm{mg} \mathrm{kg}^{-1}, \mathrm{n}=3$ ) using ICP-MS (Continuation)

\begin{tabular}{lcccc}
\hline Sample & ${ }^{75} \mathbf{A s}^{+}$ & ${ }^{114} \mathbf{C d}^{+}$ & ${ }^{120} \mathbf{S n}^{+}$ & ${ }^{208} \mathrm{~Pb}^{+}$ \\
\hline A13 & $0.027 \pm 0.002$ & $<0.0020$ & $<0.025$ & $<0.031$ \\
A14 & $0.026 \pm 0.007$ & $<0.0020$ & $<0.025$ & $<0.031$ \\
A15 & $<0.013$ & $<0.0020$ & $0.085 \pm 0.009$ & $<0.031$ \\
\hline
\end{tabular}

Table VIII. Determination of $\mathrm{Ca}, \mathrm{Fe}, \mathrm{K}, \mathrm{Mg}, \mathrm{Mn}, \mathrm{Na}, \mathrm{P}$ and $\mathrm{Zn}$ in samples of infant foods and supplements (mean \pm standard deviation, $\mathrm{mg} \mathrm{kg}^{-1}, \mathrm{n}=3$ ) using ICP OES

\begin{tabular}{|c|c|c|c|c|c|c|c|c|}
\hline Sample & $\mathrm{Ca}$ & $\mathrm{Fe}$ & K & Mg & Mn & $\mathrm{Na}$ & $\mathbf{P}$ & $\mathrm{Zn}$ \\
\hline $\mathrm{A} 1$ & $2577 \pm 21$ & $254 \pm 5$ & $922 \pm 15$ & $175 \pm 3$ & $7.5 \pm 0.2$ & $1210 \pm 12$ & $1833 \pm 11$ & $107 \pm 6$ \\
\hline $\mathrm{A} 2$ & $167 \pm 7$ & $109 \pm 5$ & $232 \pm 8$ & $23 \pm 2$ & $1.16 \pm 0.05$ & $87.5 \pm 0.4$ & $376 \pm 17$ & $52 \pm 2$ \\
\hline A3 & $41 \pm 2$ & $208 \pm 3$ & $1134 \pm 79$ & $238 \pm 7$ & $9.8 \pm 0.2$ & $84 \pm 2$ & $1228 \pm 35$ & $115.5 \pm 0.2$ \\
\hline A4 & $2492 \pm 36$ & $130 \pm 2$ & $5414 \pm 153$ & $425 \pm 7$ & $73 \pm 0.07$ & $854 \pm 20$ & $2677 \pm 36$ & $36 \pm 1$ \\
\hline A5 & $4559 \pm 118$ & $56 \pm 1$ & $7534 \pm 219$ & $343 \pm 12$ & $0.94 \pm 0.02$ & $1147 \pm 41$ & $2713 \pm 82$ & $46 \pm 2$ \\
\hline A6 & $2424 \pm 55$ & $118 \pm 4$ & $5915 \pm 18$ & $522 \pm 9$ & $10.3 \pm 0.4$ & $808 \pm 11$ & $3004 \pm 28$ & $40 \pm 1$ \\
\hline A7 & $3663 \pm 81$ & $302 \pm 15$ & $1610 \pm 25$ & $265 \pm 10$ & $11.0 \pm 0.2$ & $2112 \pm 29$ & $3015 \pm 74$ & $141 \pm 6$ \\
\hline A8 & $2635 \pm 79$ & $268 \pm 14$ & $997 \pm 30$ & $60 \pm 2$ & $1.49 \pm 0.07$ & $1681 \pm 62$ & $1820 \pm 57$ & $129 \pm 29$ \\
\hline A9 & $5771 \pm 107$ & $73 \pm 1$ & $11882 \pm 474$ & $624 \pm 8$ & $0.31 \pm 0.02$ & $1862 \pm 13$ & $3923 \pm 62$ & $49.6 \pm 0.4$ \\
\hline A10 & $2456 \pm 33$ & $344 \pm 11$ & $1539 \pm 21$ & $220 \pm 3$ & $5.6 \pm 0.1$ & $1211 \pm 16$ & $1927 \pm 16$ & $179 \pm 38$ \\
\hline A11 & $2909 \pm 80$ & $187 \pm 9$ & $3244 \pm 62$ & $575 \pm 37$ & $22 \pm 2$ & $991 \pm 34$ & $2511 \pm 89$ & $108 \pm 9$ \\
\hline A12 & $6000 \pm 156$ & $77 \pm 2$ & $10252 \pm 234$ & $584 \pm 19$ & $0.40 \pm 0.01$ & $1593 \pm 44$ & $3653 \pm 86$ & $52 \pm 1$ \\
\hline A13 & $8726 \pm 184$ & $3.6 \pm 0.4$ & $19164 \pm 246$ & $771 \pm 19$ & $0.080 \pm 0.009$ & $2772 \pm 77$ & $7699 \pm 164$ & $29 \pm 1$ \\
\hline A14 & $13475 \pm 212$ & $36 \pm 11$ & $18818 \pm 548$ & $784 \pm 21$ & $1.0 \pm 0.2$ & $2680 \pm 63$ & $8073 \pm 181$ & $94 \pm 3$ \\
\hline A15 & $2854 \pm 180$ & $42 \pm 2$ & $7767 \pm 638$ & $527 \pm 31$ & $0.69 \pm 0.05$ & $1128 \pm 56$ & $1769 \pm 108$ & $46 \pm 3$ \\
\hline
\end{tabular}

Higher concentrations of As were observed for rice-based food samples (A1, A3 and A7), which can be correlated with the known accumulation of As in rice. Unlike other cereals, rice is generally grown in flooded soils (anaerobic conditions with excess water) that provide mobilization of As and, consequently, a high accumulation of this element in the plant [28]. On the other hand, high Sn concentrations were observed for samples A5, A9, A12 and A15, all classified as infant formula. This behavior can be correlated with the metallic packaging of these formulations, known as one of the main sources of contamination of inorganic Sn [7].

For determination of macro and microelements (Table VIII), the concentration ranges determined in infant foods and supplements samples were 41 to $13475 \mathrm{mg} \mathrm{kg}^{-1}$ for Ca; 3.6 to $344 \mathrm{mg} \mathrm{kg}^{-1}$ for Fe; 232 to $19164 \mathrm{mg} \mathrm{kg}^{-1}$ for K; 23 to $784 \mathrm{mg} \mathrm{kg}^{-1}$ for Mg; 0.080 to $11.0 \mathrm{mg} \mathrm{kg}^{-1}$ for Mn; 84 to $2772 \mathrm{mg} \mathrm{kg}^{-1}$ for Na; 376 to $8073 \mathrm{mg} \mathrm{kg}^{-1}$ for $\mathrm{P}$, and 29 to $179 \mathrm{mg} \mathrm{kg}^{-1}$ for $\mathrm{Zn}$. 
According to the recommended daily intakes (RDI) from RDC no. 269 [12] and the average concentrations of $\mathrm{Ca}, \mathrm{Fe}, \mathrm{K}, \mathrm{Mg}, \mathrm{Mn}, \mathrm{P}$ and $\mathrm{Zn}$ in samples, it is possible to assign a minimum mass value of food that meets the recommendations of the Brazilian resolution for different population groups. To do so, the average concentrations of the analytes determined in the samples were grouped according to children's food indication and then a mean value was calculated for each element. Table IX shows the recommended daily intake (RDI), minimum mass of food that meets the RDI for each analyte according to the population group (infants and children) considering the mean concentrations calculated based on indication. It was observed that the intervals of minimum mass of food for infants from 0 to 6 months, infants from 7 to 11 months, children from 1 to 3 years old and children from 4 to 6 years old, are respectively from: 4 to $83 \mathrm{~g}$, 38 to $161 \mathrm{~g}, 9$ to $559 \mathrm{~g}$, and 37 to $609 \mathrm{~g}$, respectively. Considering a $5 \mathrm{~g}$ portion of sample, it was possible to calculate an average percentage of recommended daily intake (\%RDI) for the foods indicated for infants from 0 to 6 months of $6 \%$ for $\mathrm{Ca}$; $91 \%$ for $\mathrm{Fe} ; 10 \%$ for $\mathrm{K} ; 6 \%$ for $\mathrm{Mg} ; 136 \%$ for $\mathrm{Mn} ; 11 \%$ for $\mathrm{P}$; and $8 \%$ for $\mathrm{Zn}$. For a $30 \mathrm{~g}$ portion of sample, it was also possible to calculate an average \%RDI for the foods indicated for infants from 7 to 11 months, children from 1 to 3 years old and children from 4 to 6 years old ranged from 21 to $28 \%$ for Ca; 72 to $89 \%$ for Fe; 5 to $19 \%$ for K; 17 to $20 \%$ for $\mathrm{Mg} ; 22$ to $35 \%$ for $\mathrm{Mn}$; 19 to $29 \%$ for P; and 51 to $80 \%$ for $\mathrm{Zn}$. These results evidence the high nutritional potential of these foods.

Table IX. Mean concentration, recommended daily intake (RDI), minimum mass of food $(\mathrm{g})$ and average percentage of recommended daily intake for infants (0-6 months and 7-11 months) and children (0-3 years and 4-6 years) according to the chemical element

\begin{tabular}{|c|c|c|c|c|c|c|c|c|}
\hline \multirow[b]{2}{*}{ Element } & \multicolumn{4}{|c|}{ Mean concentration $\left(\mathrm{mg} \mathrm{kg}^{-1}\right)$} & \multicolumn{4}{|c|}{$\mathrm{RDI}^{\mathrm{a}}\left(\mathrm{mg}\right.$ day $\left.^{-1}\right)$} \\
\hline & $\begin{array}{c}0-6 \\
\text { months }\end{array}$ & $\begin{array}{c}7-11 \\
\text { months }\end{array}$ & $1-3$ years & 4-6 years & $\begin{array}{c}0-6 \\
\text { months }\end{array}$ & $\begin{array}{c}\text { 7-11 } \\
\text { months }\end{array}$ & $1-3$ years & 4-6 years \\
\hline $\mathrm{Ca}$ & 3707 & 3716 & 3779 & 4103 & 300 & 400 & 500 & 600 \\
\hline $\mathrm{Fe}$ & 49 & 215 & 178 & 162 & 0,27 & 9 & 6 & 6 \\
\hline $\mathrm{K}$ & 7651 & 4349 & 5363 & 6240 & 400 & 700 & 3000 & 3800 \\
\hline $\mathrm{Mg}$ & 435 & 358 & 369 & 405 & 36 & 53 & 60 & 73 \\
\hline $\mathrm{Mn}$ & 1 & 7 & 13 & 11 & 0.003 & 0.6 & 1.2 & 1.5 \\
\hline $\mathrm{Na}$ & 1138 & 1523 & 1317 & 1380 & $\mathrm{~N} / \mathrm{A}$ & $\mathrm{N} / \mathrm{A}$ & $\mathrm{N} / \mathrm{A}$ & $N / A$ \\
\hline$P$ & 2241 & 2669 & 3106 & 3211 & 100 & 275 & 460 & 500 \\
\hline $\mathrm{Zn}$ & 46 & 109 & 94 & 87 & 2.8 & 4.1 & 4.1 & 5.1 \\
\hline \multirow[b]{2}{*}{ Element } & \multicolumn{4}{|c|}{ Minimum mass of food $(\mathrm{g})$} & \multicolumn{4}{|c|}{ \%RDI } \\
\hline & $\begin{array}{c}0-6 \\
\text { months }\end{array}$ & $\begin{array}{c}7-11 \\
\text { months }\end{array}$ & $1-3$ years & 4-6 years & $\begin{array}{c}0-6 \\
\text { months }\end{array}$ & $\begin{array}{c}\text { 7-11 } \\
\text { months }\end{array}$ & $1-3$ years & 4-6 years \\
\hline $\mathrm{Ca}$ & 81 & 108 & 132 & 146 & 6 & 28 & 23 & 21 \\
\hline $\mathrm{Fe}$ & 6 & 42 & 34 & 37 & 90 & 72 & 89 & 81 \\
\hline $\mathrm{K}$ & 52 & 161 & 559 & 609 & 10 & 19 & 5 & 5 \\
\hline $\mathrm{Mg}$ & 83 & 148 & 163 & 180 & 6 & 20 & 18 & 17 \\
\hline $\mathrm{Mn}$ & 4 & 87 & 9 & 136 & 135 & 34 & 33 & 22 \\
\hline $\mathrm{Na}$ & $\mathrm{N} / \mathrm{A}$ & $\mathrm{N} / \mathrm{A}$ & $\mathrm{N} / \mathrm{A}$ & $\mathrm{N} / \mathrm{A}$ & $\mathrm{N} / \mathrm{A}$ & $\mathrm{N} / \mathrm{A}$ & $\mathrm{N} / \mathrm{A}$ & $\mathrm{N} / \mathrm{A}$ \\
\hline$P$ & 45 & 103 & 148 & 156 & 11 & 29 & 20 & 19 \\
\hline $\mathrm{Zn}$ & 61 & 38 & 44 & 59 & 9 & 80 & 69 & 51 \\
\hline
\end{tabular}

aResolution no. 269, of September 22, 2005 [12]. 
Dairy products, such as milk, yogurt and cheese, are the most Ca-rich foods in Western diets. Although grains are not particularly rich in calcium, the use of calcium-containing additives in these foods accounts for a substantial proportion of the calcium ingested by people who consume large amounts of grains [29]. In the analyzed samples, Ca occurred in higher quantities in samples A13 and A14: 8726 and 13475 mg/ $\mathrm{kg}$, respectively.

Manganese presents the lowest concentrations determined for all samples. Manganese (Mn) is an essential element, but it can also be toxic when in high concentrations. The essentiality of Mn is reflected in national and international policies on formulas and foods for children, which stipulate minimum concentrations of $\mathrm{Mn}$. Infant formula regulations have not yet been adjusted to reflect this growing body of research on neurotoxicity of $\mathrm{Mn}$; while the maximum content of $\mathrm{Mn}$ is regulated for baby formulas in some jurisdictions, others do not establish a maximum content for $\mathrm{Mn}$ in formulas for children and babies [30].

Samples A1, A7, A8, A10 and A11 had the highest concentrations of Fe. As bovine milk is a poor source of bioavailable $\mathrm{Fe}$, its use is not recommended for babies under 1 year. Inadequate early intake of cow's milk is associated with an increased risk of Fe deficiency anemia. Pediatric societies have concluded that babies who are not or are only partially fed human milk should receive an Fe-enriched formula. Supplementation is also recommended for premature babies, as their Fe stores are low [30].

\section{Comparison with other methods}

Due to the importance of monitoring elemental concentrations in infant foods, procedures for determination of macro, micro and toxic elements in children's food have been developed [31-33] Table X shows a comparison of different procedures for those determinations, highlighting a similar type of sample, cereal (porridge) rice-based, and studied elements among the cited papers [31-33].

Table X. Some procedures for determination of macro, micro and toxic elements in infant food samples

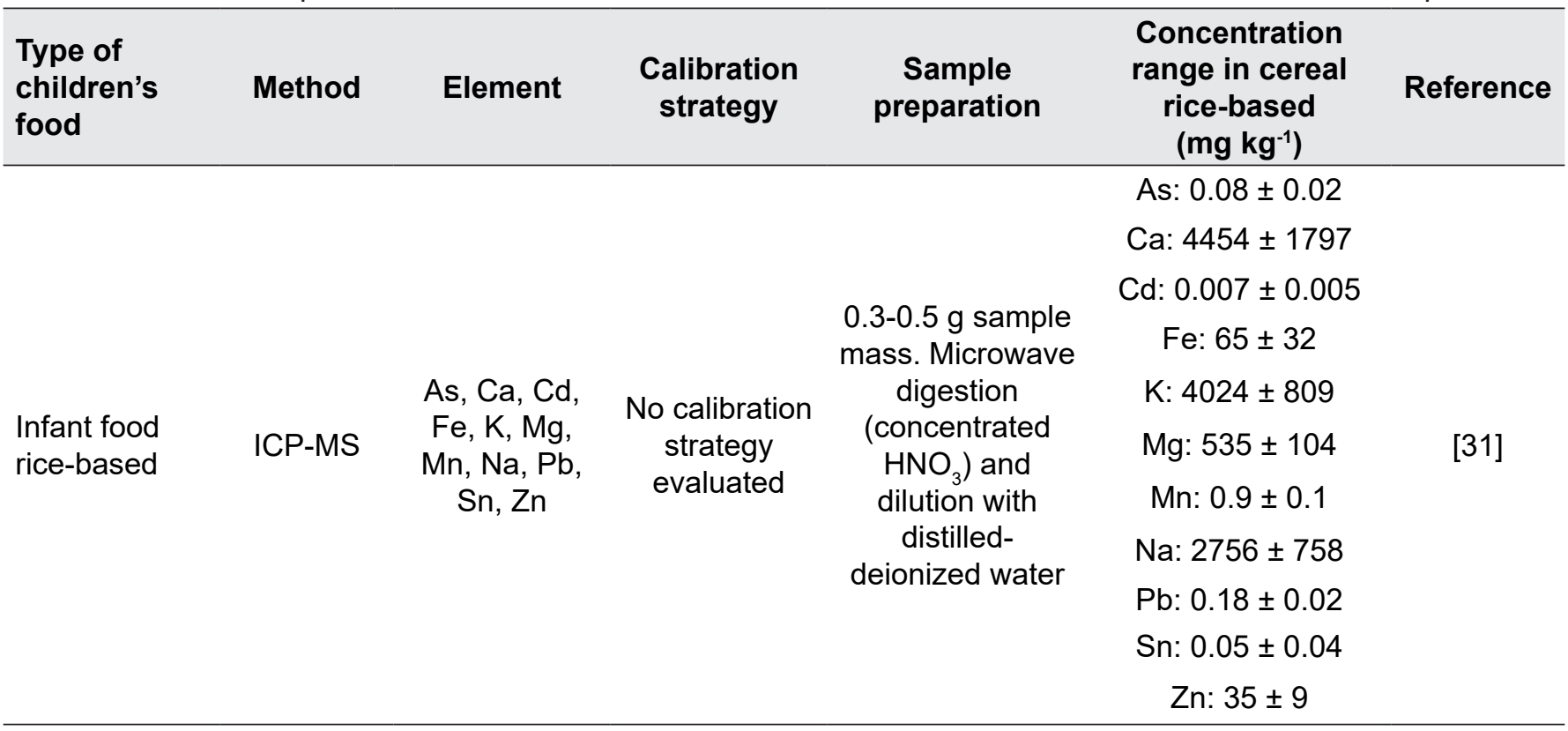


Table X. Some procedures for determination of macro, micro and toxic elements in infant food samples (Continuation)

\begin{tabular}{|c|c|c|c|c|c|c|}
\hline $\begin{array}{l}\text { Type of } \\
\text { children's } \\
\text { food }\end{array}$ & Method & Element & $\begin{array}{c}\text { Calibration } \\
\text { strategy }\end{array}$ & $\begin{array}{c}\text { Sample } \\
\text { preparation }\end{array}$ & $\begin{array}{l}\text { Concentration } \\
\text { range in cereal } \\
\text { rice-based } \\
\left(\mathrm{mg} \mathrm{kg}^{-1}\right)\end{array}$ & Reference \\
\hline $\begin{array}{l}\text { Infant formula } \\
\text { and infant } \\
\text { food }\end{array}$ & ICP-MS & $\begin{array}{c}\mathrm{As}, \mathrm{Ca}, \mathrm{Cd} \\
\mathrm{Fe}, \mathrm{Mg}, \mathrm{Mn}, \\
\mathrm{Pb} \text { and } \mathrm{Zn}\end{array}$ & $\begin{array}{c}\text { No calibration } \\
\text { strategy } \\
\text { evaluated }\end{array}$ & $\begin{array}{c}1 \mathrm{~g} \text { sample } \\
\text { mass. } \\
\text { Microwave- } \\
\text { assisted } \\
\text { digestion }(2 \mathrm{~mL} \\
65 \% \mathrm{HNO}_{3}+3 \\
\mathrm{~mL} \text { deionized } \\
\text { water) and } \\
\text { dilution with } 20 \% \\
\mathrm{HNO}_{3}\end{array}$ & $\begin{array}{c}\text { As: }^{\mathrm{a}}: 33.0 \pm 0.6 \\
\text { Ca: } 38.0 \pm 0.6 \\
\text { Cd }^{\mathrm{a}}: 1.70 \pm 0.04 \\
\text { Fe: } 1.2 \pm 0.6 \\
\text { Mg: } 127 \pm 1 \\
\text { Mn: } 3.16 \pm 0.01 \\
\text { Pba: } 1.2 \pm 0.1 \\
\text { Zn: } 1.50 \pm 0.01\end{array}$ & [32] \\
\hline $\begin{array}{l}\text { Infant food } \\
\text { and other } \\
\text { rice-based } \\
\text { products }\end{array}$ & ICP-MS & $\begin{array}{c}\mathrm{As}, \mathrm{Cd}, \mathrm{Fe} \\
\mathrm{Mn}, \mathrm{Pb} \text { and } \\
\mathrm{Zn}\end{array}$ & $\begin{array}{l}\text { Use of IS (In, } \\
\text { Y, Ge, Sc) but } \\
\text { without prior } \\
\text { analysis }\end{array}$ & $\begin{array}{l}0.15 \mathrm{~g} \text { sample } \\
\text { mass. Digestion } \\
\text { block }(1.5 \mathrm{~mL} \text { of } \\
65 \% \mathrm{HNO}_{3}+1 \\
\left.\mathrm{~mL} \text { of } \mathrm{H}_{2} \mathrm{O}_{2} 30 \%\right) \\
\text { and dilution } \\
\text { with distilled- } \\
\text { deionized water }\end{array}$ & $\begin{array}{c}\text { As: } 0.10 \pm 0.04 \\
\text { Cd: } 0.012 \pm 0.007 \\
\text { Fe: } 20 \pm 94 \\
\text { Mn: } 11 \pm 4 \\
\text { Pb: } 0.03 \pm 0.02 \\
\text { Zn: } 85 \pm 46\end{array}$ & [33] \\
\hline
\end{tabular}

As: $0.09 \pm 0.01$

Cd: $0.009 \pm 0.001$

Infant food, infant formula and children's supplements

$\begin{array}{cc}\text { ICP-MS } & \text { As, Cd, Sn, } \\ \text { and ICP } & \mathrm{Pb}, \mathrm{Ca}, \mathrm{Fe}, \mathrm{K}, \\ \text { OES } & \mathrm{Mg}, \mathrm{Mn}, \mathrm{Na}, \\ & \mathrm{P} \text { and } \mathrm{Zn}\end{array}$

Use of IS (Y, $\mathrm{Ge}, \mathrm{Pd}$ ) with prior analysis
$\mathrm{Pb}:<0.031$
Sn: $<0.025$
Ca: $3663 \pm 81$
Fe: $302 \pm 15$
$\mathrm{K}: 1610 \pm 25$
This study
Mg: $265 \pm 10$
Mn: $11.0 \pm 0.2$
Na: $2112 \pm 29$
P: $3015 \pm 74$

${ }^{\mathrm{a} C o n c e n t r a t i o n ~ i n ~}\left(\mu \mathrm{g} \mathrm{kg}^{-1}\right)$.

Similarly to the proposed procedure in reference [32], the procedure here developed also is based on a less concentrated nitric acid solution. According to these studies, concentrations of toxic elements (As, $\mathrm{Cd}$ and $\mathrm{Pb}$ ) in cereal-based samples do not pose a risk to this consumer group, despite highlighting the importance of monitoring these elements to prevent health problems. This conclusion is also true to the samples here analyzed.

\section{CONCLUSIONS}

In this study, a tailored microwave-assisted sample preparation for supplements and infant foods using only $7 \mathrm{~mol} \mathrm{~L}^{-1}$ nitric acid solution was developed. Precise and accurate determinations of As, Cd, Sn and $\mathrm{Pb}$ were performed using ICP-MS and $\mathrm{Ca}, \mathrm{Fe}, \mathrm{K}, \mathrm{Mg}, \mathrm{Mn}, \mathrm{Na}, \mathrm{P}$ and $\mathrm{Zn}$ using ICP OES. ICP-MS presents wide range of concentrations, however, thinking about laboratories that do not have the option of performing 
analyzes by ICP-MS, since it is a more expensive instrumental method, we also evaluated the ICP OES performance. ICP OES can be considered a suitable analytical method for applying the Resolution no. 269 since it is less expensive and contamination issues during sample preparation are less critical when compared to ICP-MS. For ICP-MS, the combination of instrumental strategies based on aerosol dilution and CCT as well as the use of the calibration strategy with internal standardization, allowed minimum dilution of digests and the introduction of digests with TDS of up to $0.5 \% \mathrm{~m} / \mathrm{v}$ and residual acidity of up to $1 \% \mathrm{v} / \mathrm{v}$. Considering the limits for As, $\mathrm{Cd}, \mathrm{Sn}$ and $\mathrm{Pb}$ recommended by RDC no. 193 and the RDI for Ca, $\mathrm{Fe}, \mathrm{K}, \mathrm{Mg}, \mathrm{Mn}, \mathrm{P}$ and $\mathrm{Zn}$ recommended by RDC no. 269, the developed analytical procedure using ICPMS and ICP OES presented sufficient detectability to meet both Brazilian resolutions.

\section{Acknowledgments}

The authors are grateful to the "Programa Institucional de Bolsas de Iniciação Científica", CNPq, UFSCar (PIBIC, CNPq, UFSCar) and the "Conselho Nacional de Desenvolvimento Científico e Tecnológico" (CNPq, 128923/2019-9, 141634/2017-0, 305201/2018-2 and 428558/2018-6) for fellowships and financial support. This study was financed in part by the "Coordenação de Aperfeiçoamento de Pessoal de Nível Superior Brasil” (CAPES) - Finance Code 001. Instrumental support provided by Agilent Technologies (São Paulo, SP, Brazil), Nova Analítica / Thermo Scientific (São Paulo, SP, Brazil), and Milestone (Sorisole, BG, Italy) is gratefully acknowledged. The authors also would like to express their gratitude to the "Instituto Nacional de Ciências e Tecnologias Analíticas Avançadas" (CNPq, Grant No. 573894/2008-6 and FAPESP, Grant No. 2014/50951-4) and to "Embrapa Pecuária Sudeste" - National Bank for Economic and Social Development (BNDES - 2117020010607).

\section{Conflicts of interest}

All authors declared that they have no conflict of interest.

\section{REFERENCES}

1. Brizio, P.; Benedetto, A.; Squadrone, S.; Curcio, A.; Pellegrino, M.; Ferrero, M.; Abete, M. Food Addit. Contam., Part B, 2016, 9, pp 261-267 (https://doi.org/10.1080/19393210.2016.1209572).

2. Škrbić, B.; Živančev, J.; Jovanović, G.; Farre, M. Food Addit. Contam., Part B, 2017, 10, pp 27-38 (https://doi.org/10.1080/19393210.2016.1242661).

3. Khaneghah, A. M.; Fakhri, F.; Nematollahi, A.; Pirhadi, M. Trends Food Sci. Technol., 2020, 96, pp 3044 (https://doi.org/10.1007/s11356-020-07607-9).

4. European Food Safety Authority (EFSA) Panel on Contaminants in the Food Chain (CONTAM); Scientific Opinion on Lead in Food. EFSA Journal, 2010, 8 (4):1570, pp 20-27 (https://doi.org/10.2903/j. efsa.2010.1570).

5. European Food Safety Authority (EFSA) Panel on Dietetic Products, Nutrition and Allergies; Opinion of the Scientific Panel on Dietetic products, nutrition and allergies [NDA] related to the tolerable upper intake level of tin. EFSA Journal, 2005; 3 (8):254, pp 4-9 (https://doi.org/10.2903/j.efsa.2005.254).

6. Zand, N.; Chowdhry, B. Z.; Zotor, F. B.; Wray, D. S.; Amuna, P.; Pullen, F. S. Food Chem., 2011, 128 (1), pp 123-128 (https://doi.org/10.1016/j.foodchem.2011.03.005).

7. Blunden, S.; Wallace, T. Food Chem. Toxicol., 2003, 41, pp 651-1662 (https://doi.org/10.1016/S02786915(03)00217-5).

8. Perlroth, H.; Branco, C. W. C. Jornal de Pediatria, 2017, 93 (1), pp 17-27 (https://doi.org/10.1016/j. jped.2016.0702).

9. Chaudhuri, N.; Fruchtengarten, L. Where the child lives and plays: a resource manual for the health sector. In: Pronczuk-Garbino J. (Ed). Children's health and the environment: a global perspective. World Health Organization, Geneva, 2005, pp 29-39.

10. International Agency for Research on Cancer. IARC monographs on the evaluation of carcinogenic risks to humans, volume 100 C. Arsenic, Metals, Fibres, and Dust. Lyon, IARC, France, 2017, p 11. 
11. http://portal.anvisa.gov.br/documents/10181/2862128/RDC_193_2017_.pdf/38fa96de-6f24-4a0aa872-3fe8ba5d79c7 [Accessed 05 August 2020].

12. http://portal.anvisa.gov.br/documents/33916/394219/RDC_269_2005.pdf/2e95553c-a482-45c3-bdd1f96162d607b3 [Accessed 05 August 2020].

13. Damodaran, S.; Parkin, K. L.; Fennema, O. R. Fennema's food chemistry. CRC Press, 2017, Chapter 9, p 634.

14. Oleszczuk, N.; Castro, J. T.; da Silva M, M.; Korn, M. D.; Welz, B.; Vale, M. G. Talanta, 2007, 73, pp 862-869 (https://doi.org/10.1016/j.talanta.2007.05.005).

15. Parsons, P.; Palmer, C.; Caldwell, K.; Jones, R. Determination of total mercury in urine by inductively coupled plasma mass spectrometry. In: Holland, G.; Tanner, S. (Ed). Plasma source mass spectrometry: Current Trends and Future Developments. RCS Publishing, 2006, pp 59-71.

16. Nölte, J. ICP Emission Spectrometry: A Practical Guide. Wiley-VCH Verlag GmbH \& Co. KGaA: Weinheim, 2002, p 11.

17. Nardi, E. P.; Evangelista, F. S.; Tormen, L.; Saint'Pierre, T. D.; Curtius, A. J.; de Souza, S. S.; Barbosa, F. Food Chem., 2009, 112 (3), pp 727-732 (https://doi.org/10.1016/j.foodchem.2008.06.010).

18. Pinheiro, F. C.; Babos, D. V.; Barros, A. I.; Pereira-Filho, E. R.; Nóbrega, J. A. J. Pharm. Biom. Anal., 2019, 174, pp 471-478 (https://doi.org/10.1016/j.jpba.2019.06.018).

19. Barros, A. I.; Pinheiro, F. C.; Nóbrega, J. A. Spectrochim. Acta, Part B, 2020, 167, 105825 (https://doi. org/10.1016/j.sab.2020.105825).

20. Barros, A. I.; Pinheiro, F. C.; Amaral, C. D. B.; Lorençatto, R.; Nóbrega, J. A. Talanta, 2018,178, pp 805-810 (https://doi.org/10.1016/j.talanta.2017.10.024).

21. Araújo, G. C. L.; Gonzales, M. H.; Ferreira, A. G.; Nogueira, A. R. A.; Nóbrega, J. A. Spectrochim. Acta Part B, 2002, 57, pp 2121-2132 (https://doi.org/10.1016/S0584-8547(02)00164-7).

22. Thomsen, V.; Schatzlein, D.; Mercuro, D. Spectroscopy, 2003,18 (12), pp 112-114. Available from: https://cdn.sanity.io/files/0vv8moc6/spectroscopy/3b7c7421687e0d1c3759f4549abfc2a0ab40a447. pdf [Accessed 17 August 2020].

23. Yamada, N. Spectrochim. Acta Part B, 2015, 110, pp 31-44 (https://doi.org/10.1016/j.sab.2015.05.008).

24. Amaral, C. D. B.; Machado, R. C.; Virgilio, A.; Schiavo, D.; Nogueira, A. R. A.; Nóbrega, J. A. J. Anal. At. Spectrom., 2016, 31, pp 1179-1184 (https://doi.org/10.1039/C6JA00133E).

25. Finley-Jones, H. J.; Molloy, J. L.; Holcombe, J. A. J. Anal. At. Spectrom., 2008, 23, pp 1214-1222 (https://doi.org/10.1039/B804048F).

26. Olesik, J. W.; Jiao, S. J. Anal. At. Spectrom., 2017, 32, pp 951-966 (https://doi.org/10.1039/C7JA00043J).

27. Olesik, J. W.; Jiao, S. J. Anal. At. Spectrom., 2020, 35, pp 2033-2056 (https://doi.org/10.1039/ D0JA00207K).

28. Souza, J. M. O.; Carneiro, M. F. H.; Paulelli, A. C. C.; Grotto, D.; Magalhães Jr., A. M.; Barbosa Jr., F.; Batista, B. L. Quím. Nova, 2015, 38, pp 118-127 (http://dx.doi.org/10.5935/0100-4042.20140279).

29. Otten, J. J.; Hellwig, J. P.; Meyers, L. D. The Essential Guide to Nutrient Requirements. The National Academies Press, Washington, DC, 2006, p 286.

30. http://www.fao.org/fao-who-codexalimentarius/sh-proxy/en/?lnk=1\&url=https \%253A\%252F\%252Fworkspace. fao.org\%252Fsites\%252Fcodex\%252FStandards\%252FCXS\%2B72-1981\%252FCXS_072e.pdf [Accessed 20 August 2020].

31. Al Khalifa, A. S.; Ahmad, D. Afr. J. Food Sci., 2010, 4 (7), pp 464-468. Available from: https:// academicjournals.org/journal/AJFS/article-full-text-pdf/F07D59025160 [Accessed 17 August 2020].

32. Ljung, K.; Palm, B.; Grandér, M.; Vahter, M. Food Chem., 2011, 127 (3), pp 943-951 (https://doi. org/10.1016/j.foodchem.2011.01.062)

33. Pedron, T.; Segura, F. R.; da Silva, F. F.; de Souza, A. L.; Maltez, H. F.; Batista, B. L. J. Food Compos. Anal., 2016, 49, pp 78-86 (https://doi.org/10.1016/j.jfca.2016.04.005). 